\title{
Autoimmune optic neuropathy as the first manifestation of systemic lupus erythematosus
}

\author{
Neuropatia óptica autoimune como primeira \\ manifestação do lúpus eritematoso sistêmico
}

Maria Helena Lopes Amigo', Emmanuel Casotti Duque de Bárbara², Wagner Ghirelli³

\begin{abstract}
We described a 35 years old female patient with bilateral visual loss and pain on eye movement, mild papillary edema in acute phase, arcuate scotoma and complementary test positive for antinuclear antibodies that did not respond to corticosteroid therapy. The lack of clinical criteria for systemic lupus erythematosus (SLE) didn't prevent the institution of the specific treatment with corticosteroids and azathioprine. After seven months the diagnosis was made after a skin manifestation of the disease. This case shows the value of the ocular complaints in systemic diseases. And how the ophthalmologic exam can help the clinician elaborating a diagnosis. It is also very important for ophthalmologists and rheumatologists due to the fact that it calls the attention to another diagnostic hypothesis in patients with nonspecific optic neuritis, even with inconclusive laboratory tests. Maybe some ocular findings deserve to be included to the diagnostic criteria already established for SLE.

Keywords: Optic neuritis/etiology; Optic nerve diseases/etiology; Lupus erythematosus, systemic; Collagen diseases; Case reports
\end{abstract}

\section{Resumo}

Descrevemos caso de um paciente de 35 anos do sexo feminino, com perda visual bilateral associada à dor à movimentação ocular, edema papilar moderado na fase aguda, escotoma arqueado e exame complementar positivo para anticorpos antinucleares, que não responderam à terapia com corticosteróides. A falta de critérios clínicos para o lúpus eritematoso sistêmico (LES) não impediu a instituição do tratamento específico com corticosteróides e azatioprina. Depois de sete meses, o diagnóstico foi feito após uma manifestação da doença de pele. Este caso mostra o valor das queixas oculares em doenças sistêmicas e como o exame oftalmológico pode ajudar o clínico na elaboração de um diagnóstico. Também é muito importante para oftalmologistas e reumatologistas, devido ao fato de que chama a atenção para outra hipótese diagnóstica em pacientes com neurite óptica não-específica, mesmo com os testes laboratoriais conclusivos. Talvez alguns achados oculares merecem ser incluídos com os critérios de diagnóstico já estabelecido para o LES.

Descritores: Neurite óptica/etiologia; Doenças do nervo óptico/etiologia; Lupus eritematoso sistêmico; Doenças do colágeno; Relatos de casos

\footnotetext{
${ }^{1}$ Centro de Oftalmologia Tadeu Cvintal - São Paulo (SP), Brasil;

${ }^{2}$ Centro de Oftalmologia Tadeu Cvintal - São Paulo (SP), Brasil;

${ }^{3}$ Centro de Oftalmologia Tadeu Cvintal - São Paulo (SP), Brasil;

Centro de Oftalmologia Tadeu Cvintal - São Paulo (SP), Brasil.
}

The authors declare no conflicts of interest of any order and no research funding.

Recebido para publicação em 2/8/2011 - Aceito para publicação em 4/12/2011 


\section{INTRODUCTION}

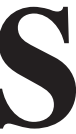
ystemic lupus erythematosus (SLE) is an inflammatory autoimmune disease that can affect multiple organs and systems. Its prevalence is higher in young women and some antibodies are found in accordance with the systemic involvement, such as: anti-DNA, anti-Sm, anti-RNP, anti-Ro (SS-A) and antiLa (SS-B), anti-histone, anti-membrane and antiphospholipid $^{(1)}$.

The most frequent ocular findings in SLE described in literature are: dry eyes, corneal epithelial erosions, mainly in the lower third of the cornea, and changes in the retinal pigment epithelium and macula ${ }^{(2)}$. Other common fundoscopic findings are the cotton wool spots, arteriolar narrowing, followed by increases in excavation and optic disc pallor ${ }^{(3)}$.

The cases described in literature presenting optic neuritis as the first manifestation of SLE had already an advanced systemic disease with retinal vascular changes, or a severe vision loss resulting in a poor visual $\operatorname{prognosis}^{(4,5)}$.

We report below a case of optic neuropathy as the first manifestation of SLE in the absence of the diagnostic criteria of the disease ${ }^{(1)}$.

\section{Case report}

A 35-year-old woman was admitted at Centro de Oftalmologia Tadeu Cvintal with pain and blurred vision in right eye $(\mathrm{OD})$ for five months and pain on movement in the left eye (OS) for three months. She had no history of ocular problems. But she had history of migraine for
18 years and endometriosis. The patient also denied having high blood pressure and diabetes mellitus.

The ophthalmologic examination revealed a best corrected visual acuity (BCVA) of 0.30 LogMAR (20/ 40) OD and 0.10 LogMAR (20/25) OS. In external examination, the ocular motility was normal and pupillary reflex were symmetric, but a slow reaction to light was noticed in both eyes. The slit lamp examination showed no alteration in cornea, iris, lens and vitreous. The applanation tensions were $15 \mathrm{mmHg}$ OD and 12 $\mathrm{mmHg}$ OS. Ophthalmoscopy revealed optic disc atrophy in the right eye and a papillary edema with arteriolar narrowing in the left (Figures 1 and 2).

The patient underwent the following tests: complete blood count (normal), erythrocyte sedimentation rate (ESR) $16 \mathrm{~mm} / 1 \mathrm{hr}$, antinuclear antibody (ANA) tested positive at a titer of $1 / 160$ and C-reactive protein $<5 \mathrm{mg} / \mathrm{L}$. Doppler ultrasound and magnetic resonance imaging of the orbit were normal. The Humphrey automated perimetry showed a superior arcuate defect affecting nasal and temporal quadrant in both eyes, but deeper in the right eye (Figures 3 and 4). After these results, the patient was treated with deflazacort $60 \mathrm{mg} /$ day.

Two weeks later, as the ocular pain and the visual impairment persisted, mainly at left (BCVA OD 0.40 LogMAR (20/50) and OS 0.30 LogMAR (20/40)) and the patient reported dry mouth sensation, the deflazacort dose was increased to $120 \mathrm{mg} /$ day. One month later, despite the treatment, the patient had no improvement on VA and pain. The papillary edema and vascular narrowing associated with the results in visual field suggested optic nerve ischemia, leading us to the
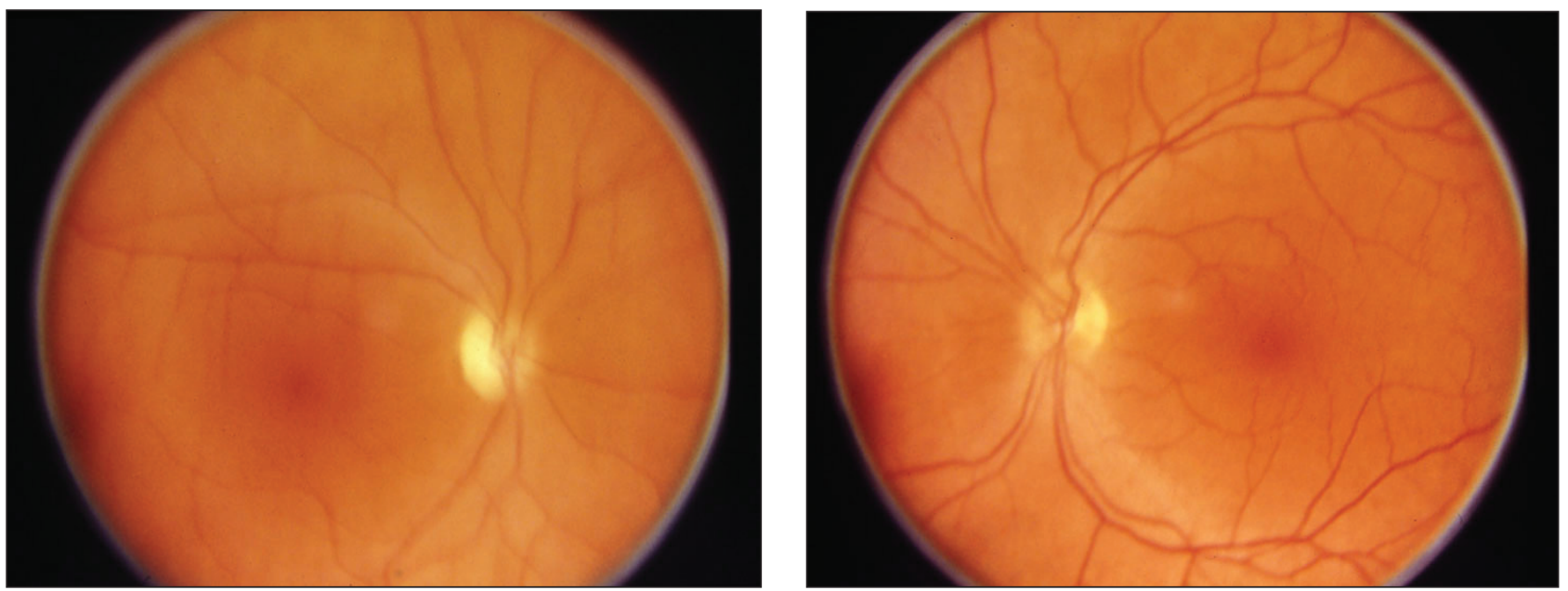

Figures 1 and 2: Optic disc atrophy OD, papillary edema and narrowed arterioles OS 


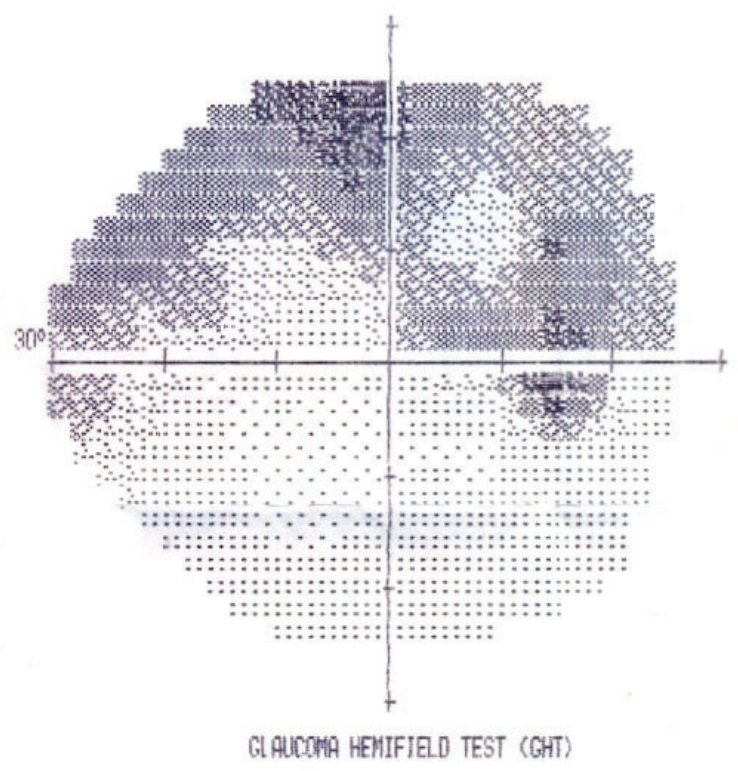

Figure 3: Automated perimetry of the right eye showing superior arcuate scotoma affecting nasal and temporal quadrant

suspicion of an optic nerve vasculitis. The patient was then referred to the rheumatologist with the suggestion of specific treatment for SLE despite the lack of clinical criteria for the diagnosis. And she was treated with prednisolone $2.5 \mathrm{mg}$ / day deflazacort $30 \mathrm{mg}$ / day and azatioprona $50 \mathrm{mg} /$ day.

After one month of the specific treatment the patient reported VA improvement and lack of pain. The BCVA was $0.30 \log$ MAR (20/40) OD and 0.18 log MAR (20/30) OS. The puppilary reflex remained slow, but ophthalmoscopy revealed no edema.

Five months later the patient had the diagnosis of SLE by a skin biopsy and hydroxychloroquine was added to the treatment at a dose of $400 \mathrm{mg}$ / day.

After 10 months of specific treatment she had BCVA 0.18 LogMAR (20/30) OD and 0.10 LogMAR $(20 / 25)$ OS. A punctate keratitis was present and ophthalmoscopy revealed bilateral optic disc atrophy. The visual field was unchanged.

Four years later, the patient presented positive tests for anti-SSA (anti-Ro) and anti-SSB (anti-La) and the ANA was positive at a titer of $1 / 640$. The BCVA was $0.10 \mathrm{log} /$ MAR (20/25) OD and 0.00 log/MAR (20/20) OS. The visual field was still unchanged.

Over the next nine years, the patient remained stable despite the advent of the keratitis. And the OCT revealed the loss of the nerve fiber layer in temporal

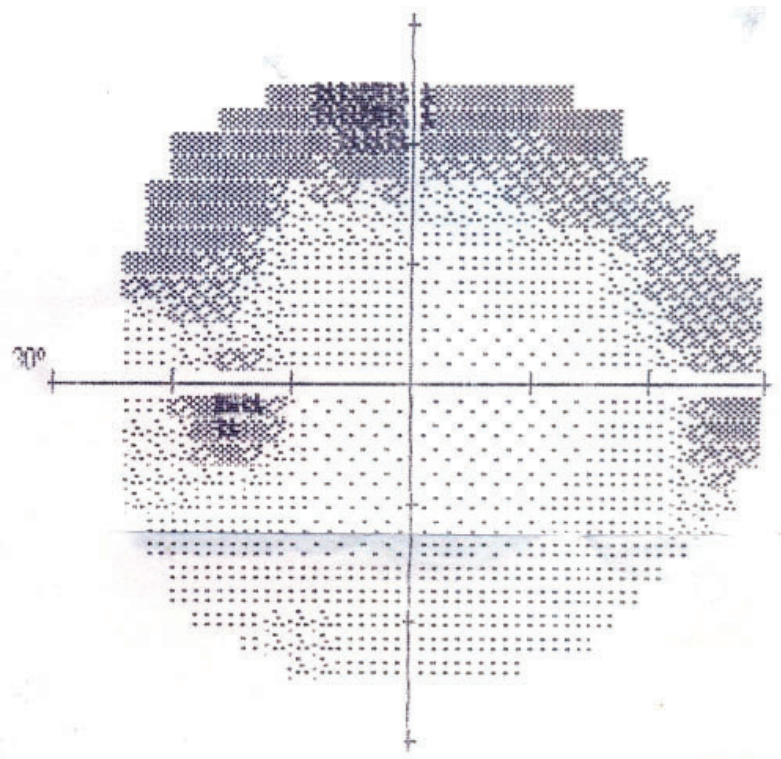

CIALCWH HEPIFIFI TEST (CHT)

Figure 4 : Automated perimetry of the left eye showing superior arcuate scotoma affecting nasal and temporal quadrants, less intense than OD

and inferior quadrants, nine years after the onset of the disease (Figure 5).

\section{Discussion}

The main cause of visual loss in patients with SLE is the retinopathy, clinically characterized by vasculitis (arteritis and periphlebitis), flame-shaped hemorrhages and cotton wool spots. Arterial and venous occlusions may be present. Such changes are found in up to $50 \%$ of patients with SLE, and these patients usually have advanced systemic disease ${ }^{(6)}$. The diagnosis in these cases becomes more difficult especially in the initial frame of the disease often presenting an evolving and often dragged atypical ${ }^{(7)}$.

Fernández Fernández et al. described a case similar to ours of optic neuritis as the first manifestation of SLE. The patient had pain on ocular movement and no clinical data suggesting lupus activity. But the delay in diagnosing SLE has led to repeated attacks of optic neuritis with $50 \%$ loss of visual acuity ${ }^{(5)}$.

The patient we described complained of vision loss but showed no sign of important retinopathy. The symptoms were due to the optic neuritis, well characterized in opthalmoscopy, pupillary reflex and visual field defects. Despite the suggestive clinical signs of an idiopathic optic neuritis, the mild papillary edema 


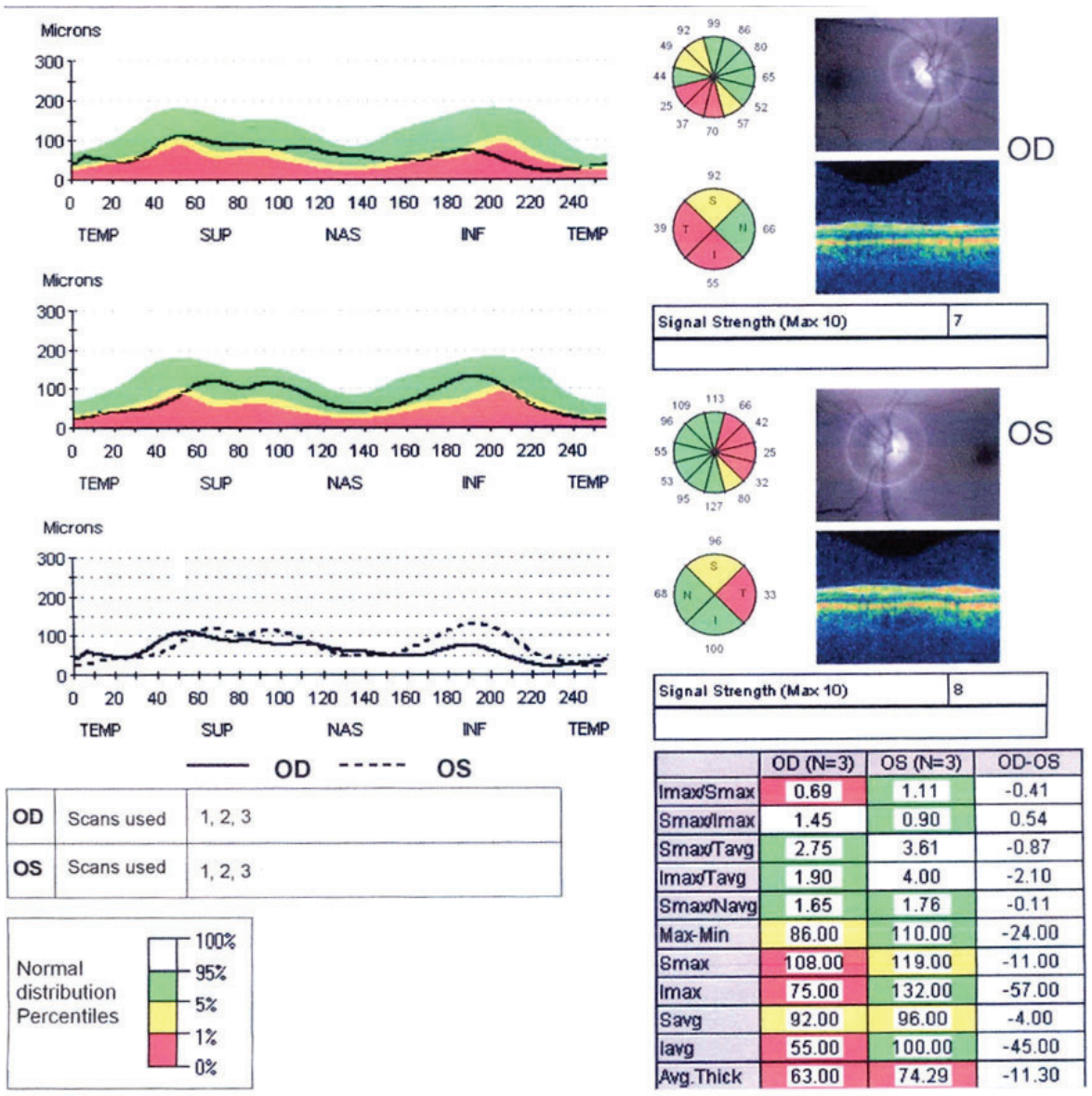

Figure 5: The papillary OCT revealing the loss of the nerve fiber layer in temporal and inferior quadrants, nine years after the onset of the disease

and visual field changes suggested an ischemic optic neuropathy affecting both eyes within a few weeks, pointing to the diagnosis of an inflammatory vascular disease.

The optic neuritis secondary to SLE is a rare manifestation, present in approximately $1 \%$ of these patients, most of whom with some degree of systemic involvement by the disease ${ }^{(6,8,9)}$. The main findings in these patients are the visual loss, the pain on ocular movement and a neuropathy caused by an ischemic process as it was observed in the present case.

There are some reports in literature of rare cases with the vision loss as the first symptom noticed by the SLE patients. In these reports, at the time of ophthalmologic examination the patient already had laboratory abnormalities consistent with the diagnosis of the disease, ${ }^{(8-11)}$ which differs from the case we reported and makes it even more interesting because, in this patient, the ocular changes preceded even the specific exams for SLE and the diagnostic criteria were only met about 7 months after the first ocular manifestations.

Autoimmune optic neuropathy can occur as a manifestation of a vascular connective tissue disease. It responds well to corticosteroid therapy and can become steroid dependent, unlike our patient who did not respond to massive doses in the treatment. Another difference is the symptoms, where the autoimmune optic neuritis usually is not accompanied by orbital pain ${ }^{(12,13)}$.

This case shows the value of the ocular complaints in systemic diseases. And how the ophthalmologic exam can help the clinician elaborating a diagnosis.

It is also very important for ophthalmologists and rheumatologists due to the fact that it calls the attention to another diagnostic hypothesis in patients with nonspecific optic neuritis, even with inconclusive laboratory tests. And maybe some ocular findings deserve to be included to the diagnostic criteria already established for SLE. 


\section{ReferenCeS}

1. Hillmann DB. Arthritis \& musculoskeletal disorders. In: Tierney LM Jr, McPhee SJ, Papadakis MA, editors. Current medical diagnosis \& treatment. 36th ed. Stamford: Prentice Hal; 1997. 20:774-7.

2. Mendes LE, Gonçalves JOR, Costa VP, Belfort Junior R. Alterações oculares no lúpus eritematoso sistêmico. Arq Bras Oftalmol. 1998;61(6):713-6.

3. Bigolin S, Oyamaguchi E, Claro C, Bryk Junior A, Komatsu MCG, Belotto E, Postella E. Achados oculares e fundoscópicos em pacientes com lúpus eritematoso sistêmico. Arq Bras Oftalmol. 2000;63(5):383-6.

4. Im CY, Kim SS, Kim HK. Bilateral optic neuritis as first manifestation of systemic lupus erythematosus. Korean J Ophthalmol. 2001;16(1):52-8.

5. Fernández Fernández FJ, Fernández Larrañaga JR, Pérez Fernández S, Rodríguez Ríos M, Mardomingo Varela P.Optic neuritis as first manifestation of systemic lupus erythemathosus]. An Med Interna. 2004;21(7):366.Spanish.

6. Wong K, Ai E, Jones JV, Young D. Visual loss as the initial symptom of systemic lupus erythematosus. Am J Ophthalmol. 1981;92(2):238-44.

7. Riedel P, Wall M, Grey A, Cannon T, Folberg R, Thompson HS. Autoimmune optic neuropathy. Arch Ophthalmol. 1998;116(8):1121-4.
8. Traboulsi EI, Manso AM, Aswad MI, Gharzuddin W, Frayha RA. Homonymous hemianopia and systemic lupus erythematosus. J Clin Neuroophthalmol. 1985;5(1):63-6.

9. Ahmadieh H, Roodpeyma S, Azarmina M, Soheilian M, Sajjadi AH. Bilateral simultaneuous optic neuritis in childhood systemic lupus erythematosus. A case report. J Neuroophthalmol. 1994;14(2):84-6.

10. Sklar EM, Schatz NJ, Glaser JS, Post MJ, ten Hove M. MR of vasculitis-induced optic neuropathy. AJNR Am J Neuroradiol. 1996;17(1):121-8.

11. Jabs DA, Miller NR, Newman SA, Johnson MA, Stevens MB. Optic neuropathy in systemic lupus erythematosus. Arch Ophthalmol. 1986;104(4):564-8.

12. Kupersmith MJ, Burd RM, Warren FA, Klingele TG, Frohman LP, Mitnick H. Autoimmune optic neuropathy: evaluation and treatment. J Neurol Neurosurg Psychiatry. 1988;51(11):13816. Erratum in J Neurol Neurosurg Psychiatry. 1989;52(5):692.

13. Cardoso LMCD, Zacharias LC, Monteiro MLR. Neuropatia óptica auto-imune: relato de caso. Arq Bras Oftalmol. 2006;69(4):593-5.

\section{Corresponding author:}

Wagner Ghirelli

Rua Maria Figueiredo, $\mathrm{n}^{\circ} 283$

Phone: 55 - 11 - 3371-3324

E-mail:wagnerghirelli@yahoo.com.br 